"Female directorship, director compensation, managerial shareholding, and price-earnings multiple of Nigerian firms"

\begin{tabular}{ll} 
AUTHORS & $\begin{array}{l}\text { Isah Shittu } \\
\text { Ayoib Che Ahmad } \\
\text { Zuaini Ishak (D https://orcid.org/0000-0002-9971-4606 } \\
\text { Isah Shittu, Ayoib Che Ahmad and Zuaini Ishak (2016). Female directorship, } \\
\text { director compensation, managerial shareholding, and price-earnings multiple of } \\
\text { Nigerian firms. Problems and Perspectives in Management, 14(2), 56-66. } \\
\text { doi:10.21511/ppm.14(2).2016.06 }\end{array}$ \\
\hline ARTICLE INFO & http://dx.doi.org/10.21511/ppm.14(2).2016.06 \\
\hline DOI & Wednesday, 11 May 2016 \\
\hline RELEASED ON & "Problems and Perspectives in Management" \\
\hline JOURNAL & LLC "Consulting Publishing Company "Business Perspectives" \\
\hline FOUNDER &
\end{tabular}

NUMBER OF REFERENCES

0

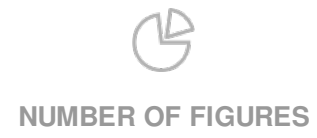

0

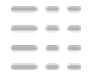

NUMBER OF TABLES

0

(C) The author(s) 2022. This publication is an open access article. 
Isah Shittu (Malaysia), Ayoib Che Ahmad (Malaysia), Zuaini Ishak (Malaysia)

\title{
Female directorship, director compensation, managerial shareholding, and price-earnings multiple of Nigerian firms
}

\begin{abstract}
The failure of business entities across the globe has continued to draw the attention of stakeholders of those entities. Due to these problems, different countries issued corporate governance regulations to avoid the repeat of the past. Part of the aims of these CG guides is to increase firm value. In Nigeria, similar guidelines issued for firms are referred to as codes of CG. However, arguments exist between stakeholders on whether those corporate governance mechanisms increase the value of shareholders. Some investment analysts suggest the consideration of governance mechanism before investment, while some argue that CG practices are not necessary for Nigeria. To address this problem, this research empirically examines the effects of female directorship, director compensation and managerial shareholding on price-earnings multiple of Nigerian firms. The research uses data from 100 firms listed in the Nigerian Stock Exchange (NSE). The study used the generalized method of moments (GMM) to estimate the regression due to endogeneity problem amongst the variables. The study reveals a significant positive association between female directorship, director compensation, managerial shareholding and price-earnings multiple at $10 \%, 1 \%$ and $10 \%$, respectively. Therefore, it recommends additional females on board, compensation for directors and more managerial share ownership.
\end{abstract}

Keywords: female directorship, director compensation, managerial shareholding, price-earnings multiple, Nigerian Stock Exchange.

JEL Classification: M41.

\section{Introduction}

Price-earnings multiple also referred to as company market multiple is used to evaluate the market price of equity adjustable to some particular value driver's earnings and book value, for example. PE multiple is among the equity valuation multiples (EVM) available in the literature which presents market opinion of companies comparative to its competitors (Penman, 2006). The price-earnings (PE) appraisal technique estimates firm's stock price as the formation of earnings (Alford, 1992). Price-earnings multiple is, essentially, used by business investment analysts to appraise stock performance. Shareholders that invest their money in a firm in form of stockholders generally have the interest of evaluating the amount of yield from capital invested. In buying company shares, it is common for a stockholder to consider the sum of money paid as a multiple of earnings per company share and what the company makes (Damodaran, 2006; Mosley \& Singer, 2008). Historical PE multiple is proposed as the greatest market valuation technique towards forecasting price returns (Sehgal \& Pandey, 2010). PE multiple as one of the valuation multiples is established to have superior performance in contrast to other equity valuation multiples (Antonios, Ioannis \& Panagiotis, 2012). Other equity valuation available in the literature includes price-book value, price-cash flow, and price-sales multiples. As observed in the study of Schreiner (2007), the price-earnings multiple

(c) Isah Shittu, Ayoib Che Ahmad, Zuaini Ishak, 2016.

Isah Shittu, School of Accountancy, College of Business, Universiti Utara Malaysia, Malaysia.

Ayoib Che Ahmad, School of Accountancy, College of Business, Universiti Utara Malaysia, Malaysia.

Zuaini Ishak, School of Accountancy, College of Business, Universiti Utara Malaysia, Malaysia. will continue to attract the responsiveness of market partakers because of its straightforwardness in computation among different firms.

On the other hand, corporate governance (CG) variables are usually observed as real tools for the existence of the corporate body. The ability of business organizations to introduce sound governance systems guarantees their survival. The attention of the investing public became more pronounced to corporation's governance practices after the failure of giant corporations in the world that include Enron and WorldCom. The global financial crisis triggered total shutdown of several corporate organizations subjecting investors (local and foreign) to losses in the value of their stocks. Correspondingly, after the crisis, various regulatory changes are carried out with objective to avoid such problem in the future. Evaluating such provisional changes in relation to value of shareholders of the respective companies is very imperative. Diversification of board membership regarding gender representation is seen as one mechanism that enhances monitoring capacity of the board thereby increasing the value of owners. The regulatory authorities recommend to all firms to consider gender issue in formation of corporate boards. But little evidence is available on the role of female directorship serving on company, especially in emerging economy like Nigeria. Similarly, compensation for directors is regarded as one of the ways to control the excessiveness of self-serving directors. This is because their temptation to company resources could be minimized due to the proper compensation package. On the issue of managerial shareholding as a corporate control mechanism against agency problem, researchers and other stakeholders suggested 
managerial shareholding as one of the mechanisms that control agency problem. However, studies on female directorship, director compensation and managerial shareholding produce conflicting results. While most of the studies established a positive relationship between these variables and owners value, other found no relationship. The majority of the previous literature on governance and performance relationship concentrates more on other measures of performance, for example, Tobin's q, return on capital employed (ROCE), profitability, asset growth and return on asset. To the best of our knowledge, no study empirically investigated the effect of these CG variables and price-earnings multiple in developing economy, particularly, of Nigeria. Also, most of the prior literature on female directorship, director compensation and managerial shareholding in relation to firm value is in developed economy, not much is known in developing economy. Hence, this study empirically investigated the influence of these governance mechanisms on the price-earnings multiple of Nigerian firms.

Furthermore, literature has established a causal relationship between corporation governance practices and performance relationship. This means that as governance practices influence performance, good company performance could also lead to the implementation of governance practices by companies. Therefore, estimating any regression based on the static panel regression (ordinary least square (OLS), fixed and random effect) models could lead to regression bias. This is because of endogeneity problem established in the literature between governance and value. This study empirically examined the effect of female directorship, director compensation and managerial shareholding on the price-earnings multiple using the dynamic model. The objective of using dynamic model generalized method of moments (GMM) is to address the endogeneity problems envisaged between the dependent and the independent variables. This study, therefore, provides methodological, practical and literature contribution. The next section presents previous works on the governance and performance relationship for the study hypotheses.

\section{Literature and hypotheses and theoretical background}

1.1. Female directorship. In recent periods, there is an increased demand on companies in both US and the UK to increase the mixture of their company board memberships. In the UK, for instance, Higgs' report (2003) proposed that companies look at ways of increasing their board diversity for effectiveness. Gender is one of the dimensions of the diverse board. In Nigeria, SEC code recommends consideration of age and gender representation in corporate board composition. However, researches conducted on the association between firm board gender diversity and value of firms produced mixed results. For instance, the research of Farrell and Hersch (2005) established that women incline to work on better performance firms, and substantial returns are recorded whenever an announcement is made for additional women joined the firm board. Similarly, Carter et al. (2003) study African-American and Asian-American proportion of women serving on American firms boards and report a substantial positive association between women on the board and value of firm. Shareholders are more likely to respond to gender diversified board (Kang \& Ding, 2009). Also, Miller (2009) studied the Fortune 500 firms and established a positive association between company board gender diversity and company value. Moreover, Morey et al. (2009) studied 200 companies from 21 different markets and reported a significant positive association between company board gender and higher market valuation of firms. Similarly, Gul, Srinidhi and $\mathrm{Ng}$ (2011) document that gender diversity of board members increases stock price through the device of public information disclosure in larger firms and by boosting confidential evidence gathering in smaller firms. The companies with more female directors have more performance in relation to return on equity and Tobin's q (Terjesen, Couto \& Francisco, 2015). Companies with a greater number of females on the board of directors have adopted restrained towards earnings management practices amongst the UK firms (Arun, Almahrog \& Ali Aribi, 2015). Furthermore, Dezso (2012) used 15 year pool data on the firm board and upper management Standard and Poor (S\&P) 1.500 and established that female representation in the top firm management improves values. To add, Adams and Ferreira (2009) found that female directors have a significant impact on board inputs and firm performance in selected US firms. Female representation on higher management increases firm performance, however, only to the degree that a company's plan is focused on improvement, in which setting the informational and societal advantages of behavior and gender diversity are related with females in management (Dezso \& Ross, 2012). Female directors generate value for some Malaysian firms, however, decrease the value in others (Abdullah, Ismail \& Nachum, 2016). The presence of female on board has negative association with firms disclosure (Muttakin, Khan \& Subramaniam, 2015).

On the contrary, other studies could not establish any relationship between board gender diversity and firm's value. For instance, Fenwick and Neal (2001) could not find any significant correlation between gender group structure and market value of equities. Equally, Fenwick and Neal (2001) and Rose (2007) studied a sample of listed Danish companies and 
established that Danish boards are to a significant level controlled by men directors. The research could not find any significant relation between firm value and female representation in the board. There is a negative association of having multiple females on the board and the subsequent company performance (Chapple \& Humphrey, 2013). The firms with high female presence among nonexecutive and executive directorships do not result in significant differences both in service quality and financial return (Ellwood \& Garcia-Lacalle, 2015). The representation of females on boards negatively affects the performance of small firms (Adams, 2015). The above highlighted discussions on studies of female representation on company board and value of firms produced conflicting findings, thus, this study hypothesizes the following:

H1. Female directorship on board has a significant positive relationship with price-earnings multiple of Nigerian listed firms.

1.2. Director compensation. Proper compensation to directors is suggested as one of the incentives that will motivate the directors always act on the overall interest of the company. Thus, the director compensation serves as one of the CG monitoring devices. However, in certain situations, some directors manipulate the company account to claim more reward from the owners, the case of Enron, for example. To achieve reasonable and fair compensation plan, regulatory authorities in Nigeria recommend approval of the board for compensation of the executive directors. While compensation of non-executive directors must be fixed by the board, approval of the shareholders is required at company annual general meeting (AGM). Compensation for company directors differs from industry to industry and within the industry across companies.

The pay to directors performance strategy usually helps to reduce the problem of CG in a company (Phan, 2001). Mehran (1995) examined executive director compensation structure of 153 sampled manufacturing firms from 1979 to 1980 and established evidence supporting incentive compensation for company directors. Perry and Zenner (2001) conducted research on pay and performance relationship and found that incentive based compensation for company directors influences the degree of monitoring, and companies can align directors and shareholders interest. Similarly, Hermalin and Weisbach (1998), in their research, suggested that motivation pay for company directors and management could enhance the monitoring capacity executed by the board of directors. Also, Healy (1985) finds evidence that executive directors choose revenue increasing investment in order to maximize the existing value of bonus component of their benefit in the firm. Executive compensation is greater in shares with higher liquidity and is possible to have better unsophisticated stockholder participation (F. Li \& Subrahmanyam, 2009). Equity-based compensation for chief executive officer is related to annual stock option and stock grants (Masulis, Wang $\&$ Xie, 2014). Banks whose chief executive officers have higher pay for performance have significant better abnormal share returns nearby the acquisition announcements (Minnick, Unal \& Yang, 2009). The pay to directors is tied to long-term firm performance, thereby increasing the value of shareholders (Cheng, Hong \& Scheinkman, 2015).

In contrast to the above findings, Core et al. (1999) examined 205 US firms from 1982-1984 and established that firms that have weak boards and lacks in block ownership permit CEOs to take excessive compensation that results in the worst subsequent value of firm. Buttressed by Yeo, Chen and Lee (1999) in the study of 56 listed firms in Singapore from 19831993 found no significant proof for the motivation influence of directors stock compensation plans (ESOP), and stock price increase, and operational performance of Singapore firms. Jensen and Murphy (1990) established a weak association between compensation for directors and subsequent company performance. Equally, reports fall in both levels of chief executive officer pay per year and the pay to performance relationship. Similarly, Campbell and Wasley (1999) established that executives can occasionally structure compensation policies at the detriment of shareholders. Brick, Palmon and Wald (2006) tested a model on the relationship between chief executive officer and directors compensation and firm value evidence from the results suggesting that excessive compensation for the duo leads to firm underperformance. The firms that provide the CEO, the external directors, or both with equity options increase the firm risk taking culture (D. Li, Eden, Hitt $\&$ Ireland, 2008). The studies conducted on director compensation and performance continue to produce mixed findings. Therefore, the present study makes the following proportion:

H2. Director compensation has significant positive relationship with the price-earnings multiple of Nigerian listed firms.

1.3. Managerial shareholding. Ownership of stocks by management is regularly recommended as one of the corporate monitoring devices. The stake of managers in company equity encouraged them to work diligently for the success of the corporation. Managers will take adequate measures to evade unethical matters that may affect the company value. The issued CG codes in Nigeria made clear provisions on share ownership of management to ensure fairness in all company dealings. Researchers debated on managers 
share ownership as a control mechanism and firm values, and the results are missed suggesting further investigation. For instance, Demsetz and Lehn (1985) argue that managerial owners can be considered potential managers of equity agency problems. Therefore, an increase in their shareholdings gives them a stronger incentive to monitor the performance of the firm. On their part, Short and Keasey (1999) studied the relationship of insider ownership (directors and management) and shareholders return on equity in agreement to the entrenchment of 225 sampled firms listed in the London Stock Exchange. The research reports a positive and significant association at higher levels of directors and management shareholdings. This is in agreement with the alignment of management and shareholder's interests. Similarly, Stulz (1988) presented a model postulating that great share ownership by company managers and the related voting power permit managers to be more probably entrenched in their specific positions within the firm. Increase in return of equity of selected US companies is dominated by share ownership of managers and directors of the companies (Baker, 1988). Shleifer and Vishny (1997) detect the relationship concerning pay and performance as problem issue; they explain that the ultimate way to decrease agency problem is through increasing shares ownership of directors and other managers in the company. Managerial share ownership has significant positive influence on the joint stock return of 800 selected firms of East Asian countries during the period of financial crises (Lemmon \& Lins, 2003). Ownership of directors has an effect on the abnormal returns of companies listed on the London Stock Exchange (Fidrmuc, Goergen \& Renneboog, 2006). Furthermore, Denis, Denis and Sarin (1997) proposed model of ownership of the company and higher managers' income as a function, in agreement with manager's entrenchment. The researchers found that highest management turnover is vividly higher in companies that report poor stockholder's returns with small management and directors share ownership than in firms that are performing poorly with higher managerial ownership. Directors' and managers' share ownership is significantly associated wtih a company value of 60 listed firms during initial public offering (IPO) in Finland (Keloharju \& Kulp, 1996). Additionally, Meek, Roberts and Gray (1995) detected that firm directors may reveal voluntarily information where that information will impact their own individual interest. Where directors own the corporation shares and their individual interest coincides with that of shareholders, they will pay additional attention to corporation share price, which absolutely reflects the company prospects and performance.
Despite results from previous studies reported a positive association between the dependent and the independent variables, others could not find any link between the amount of shares owned by management and firm performance. For example, Sanda et al. (2005) studied the CG variables and performance of 93 listed firms in the NSE during 1996-1999. The research reports no significant association between ownership of directors and price-earnings ratio of the selected firms. Similarly, Dadidson, Rosenstein and Sundaram (2002) reported a negative relationship between stock held by inside directors and abnormal stock returns of 94 selected firms in the US during 1985-1991. Managerial share ownership in Malaysian corporations has a significant negative association with a total cost of monitoring as projected by the convergence of interest proposition and agency theory (Mustapha \& Che Ahmad, 2011). Deducting from the discussions above, mixed results exist between managerial share ownership and firm performance, thus, our study proposed the following hypothesis:

H3. Managerial share ownership has a significant positive relationship with price-earnings multiple of Nigerian listed firms.

1.4. Theoretical background. The agency theory explains those relationships that exist between principals (providers of capital) and agents (managers). The theory is aimed at providing solutions on the problems that could exist between the two conflicting interest groups: shareholders and managers. Hjelmstad, Marshall and Walmsley (2006) acknowledged that constructive market reactions associated with open market stock repurchases in the UK are better explained by agency theory. Similarly, Phan (2001) argued whether agency theory expectations can be general to emerging markets, in spite of their economical, sociological and developing differences, thus, concludes the theory apply to emerging markets. In the Nigerian corporate setting, agency theory is considered as a serious problem, especially in public corporations where stockholders are spread across the state and abroad. The combined report issued by the Nigerian Deposit Insurance Corporation (NDIC, 2009) and the Central Bank of Nigeria (CBN, 2011) indicated several CEOs of public corporations for using their respective positions to defraud their organizations. Stockholders in the affected companies have suffered due to the selfserving managers (agents) problem. Thus, this study examined the influence of female directorship, director compensation and managerial shareholding in predicting price-earnings multiple of Nigerian firms from agency theory perspective.

1.5. Control variables. Control variables in research of this nature are important as the explained and the explanatory variables (Becker, 2005). They provide 
solutions in ruling out additional explanations of results, decreasing the influence of the model error terms and increasing the statistical strength of the regression model. Some control variables that are available and used in the literature include firm size, risk, firm age, leverage, audit type, industry specific and year, amongst others. Since, the objective of this study is to examine empirically the relationship between female directorship, director compensation, and managerial shareholding, and PE multiple of Nigerian firms. This study controls for firm size, firm age, industry, risk and year to ensure the accuracy and dependability of our result interpretation. The control for the aforementioned variables is required due to the distinctiveness of the companies under the model. The objective for controlling for the above variables is to avoid the likelihood of spurious regression results. Control variables in organizational research reduce error term effect in the regression and help towards improving the statistical impact of independent variables (Loderer \& Waelchli, 2009; Pagano \& Schivardi, 2003).

\section{Methodology}

This research employed descriptive research design to investigate the effect of $\mathrm{CG}$ variables (female directorship, director compensation and managerial shareholding on the price-earnings multiple of Nigerian firms). The used information is published in the annual reports, and relevant publications justified the choice of the research study design. Research data are handily collected from the available reports of the companies operating on the Nigerian Stock Exchange for (2009-2013) five (5) years period. This period is the post-world financial crisis period that affected virtually all countries of the world, including Nigeria. The research population consists of public listed companies on the NSE, and 100 firms are selected. Availability of information of the study variables serves as the basis for selection of the sample. The literature has a proven causal association between corporate governance $(\mathrm{CG})$ variables and performance relationship (Delgado-García, Quevedo-Puente \& Fuente-Sabaté, 2010). Therefore, estimation using the static panel regression model (pool OLS, random and fixed models) could not be appropriate. Therefore, this study chose generalized method of moments (GMM) to solve the problem of endogeneity that exists between the dependent and the independent variables.

The estimation technique used in the study by Arellano and Bond (1998) and Blundell \& Bond (2000) is generalized method of moments (System GMM). The estimator has certain advantage that comprises the following control for the likely problem of endogeneity of independent variables, it avoids non-observable limit heterogeneity growing from specific structures of each firm that persist over a period. Moreover, this estimation technique permits the introduction of more instruments than other estimators, which enhances proficiency. To make the result of GMM more robust and reliable, the following test Hansen $\mathbf{J}$ is conducted for over identification to check the strength of the model. Arellano and Bond use a test of endogeneity before and after the estimation and all the conditions are satisfactorily fulfilled.

Table 1. Variable definition and measurement

\begin{tabular}{|c|c|}
\hline CG mechanisms & Measurements \\
\hline $\begin{array}{l}\text { Price-earnings multiple } \\
\text { Female directorship }\end{array}$ & $\begin{array}{l}\text { Stock price per share divided by earnings per share } \\
\text { Number of female directors on the firm's board }\end{array}$ \\
\hline Director compensation & Compensation for directors total pay \\
\hline Managerial shareholding & Total share ownership for directors including executives \\
\hline \multicolumn{2}{|l|}{ Control variables } \\
\hline Firm size & Measured by log of total asset \\
\hline $\begin{array}{l}\text { Firm age } \\
\text { Industry type } \\
\text { Year } \\
\text { Risk }\end{array}$ & $\begin{array}{l}\text { The difference between } 2013 \text { and company year of listing in the NSE } \\
\text { Industry dummies based on financial and non-financial firms } \\
\text { Year dummy } \\
\text { Firm dummies for risk management committees one and zero }\end{array}$ \\
\hline
\end{tabular}

Note: variables definition and computations are extracted for every firm over the study period.

Most of the prior works on CG and performance relationship used static panel regression model (pool OLS, random and fixed). Nevertheless, literature has recognized the causal relationship between company governance variables and performance. This research used the dynamic model GMM (generalized method of the moment) to solve endogeneity problem between the variables of the research. Therefore, the study presents the model specified below:

$$
P E_{i t}=\beta_{0}+\beta P E_{i t-1}+\beta_{1} F D_{i t}+\beta_{2} D C_{i t}+\beta_{3} M S H_{i t}+\lambda_{i}+\varepsilon_{i t}
$$

From the model above, $P E$ represents price-earnings multiple, $F D$ is female directorship, $D C$ is for director compensation, and $M S H$ is for managerial shareholding. I refers to the element of observation; $t$ refers to the time, $\beta_{0}$ is the constant; $\beta$ is the coefficient of the lagged dependent variable; $\beta_{1}$ is coefficient of independent variables; $\lambda$ is precise unobserved effect; $\varepsilon$ is the residue of the error term. 


\section{Results and discussions}

This section presents the summary of descriptive statistics, correlation matrix and GMM panel regression results. The summary statistics presents the mean values, standard deviation, minimum and maximum values.

Table 2. Summary of descriptive statistics

\begin{tabular}{|l|c|c|c|c|c|}
\hline \multicolumn{1}{|c|}{ Variable } & Obs & Mean & Std. deviation & Min & Max \\
\hline PE & 500 & 15.5957 & 33.07085 & 0.07 & 625 \\
\hline FD & 500 & 3.898 & 0.9846497 & 3 & 8 \\
\hline DC & 500 & 0.16204 & 0.2774234 & 0 & 2.6 \\
\hline MSH & 500 & 98569 & 0.33243028 & 0 & 2 \\
\hline RIS & 500 & 0.524 & 0.5039165 & 0 & 68 \\
\hline NSEAGA & 500 & 22.68 & 14.42407 & 4 & 9.59 \\
\hline SIZE & 500 & 7.278 & 0.8806313 & 5.71 & 1 \\
\hline INDUS & 500 & 0.3 & 0.4587165 & 0 & 1 \\
\hline YDUMMY5 & 500 & 0.2 & 0.4004006 & 0 & \\
\hline
\end{tabular}

Note: PE represents price-earnings multiple, FD is female directorship, DC is director compensation, and MSH is managerial shareholding, RIS is risk, NSEAGE is company listing age, SIZE is size of the firm measured by log of total asset, INDUS is firm industry specific, YDUMMY is year dummy for the study period (5 years).

Table 2 above provides the mean value of 15.59 for PE with the minimum and the maximum values 0.07 and 625 , respectively. The mean value of the female directorship is 3.89 ; the minimum value is 3 and the maximum is 8 directorships. The mean value for director compensation is 0.16 ; the minimum value is 0 and the maximum is 2.6. The mean value for managerial shareholding is 98569 , while the minimum is 0 and the maximum is 2392340 . The other aspect of the descriptive statistics is the standard deviation (SD) for normality of the variables (explained and explanatory). The explained variable has the highest standard deviation of 33.07 which is normal considering the nature of the spreads in the stock market prices of the sample firms. The standard deviation of the explanatory variables is 0.98 for female directorship; 0.28 is for director compensation and 0.33 is for managerial shareholding. A cross check of the standard deviations suggests that deviations from the mean are not high, indicating the normality and reliability of the study variables. The subsequent Table presents correlation matrix of the study.

Table 3. Correlation matrix results

\begin{tabular}{|l|c|c|c|c|c|c|c|c|}
\hline & PE & FED & DIRC & MSH & RISK & NSE & IND. & YRD \\
\hline PE & 1.0000 & & & & & & & \\
\hline FEMALE & $0.1090^{\star \star \star}$ & 1.0000 & & & & & & \\
\hline DIRCOM & $0.0199^{\star \star}$ & -0.0419 & 1.0000 & & & & & \\
\hline MSH & $0.0215^{* \star}$ & 0.0519 & 0.2583 & 1.0000 & & & & \\
\hline RISK & 0.0316 & 0.2089 & -0.0631 & 0.0359 & & & & \\
\hline NSE & $-0.0033^{\star \star *}$ & -0.0281 & -0.1998 & -0.4002 & 1.0000 & & & \\
\hline SIZE & $0.0267^{* \star}$ & 0.4036 & -0.2000 & -0.0454 & 0.0299 & 1.0000 & & \\
\hline INDUST & 0.0616 & 0.3785 & 0.0634 & 0.1225 & -0.2247 & 0.4390 & 1.0000 & \\
\hline YRDUM & -0.0060 & 0.1281 & -0.0035 & -0.0000 & 0.0000 & 0.0586 & 0.0000 & 1.0000 \\
\hline
\end{tabular}

Note: GMM regression is significant at $* * * 1 \%, * * 5 \%$ and $* 10 \%$.

The correlation matrix results as present in Table 3 above show a positive correlation of 0.1090 between the PE and female directorship. The correlation between PE multiple and director compensation is 0.0199 , while the correlation of PE multiple to managerial shareholding also stands at 0.0215 . Nevertheless, the correlation coefficient between the dependent variable PE and the independent variables managerial shareholding, female directorship and director compensation has no perfect correlation. This suggests that the variables are within acceptable limit, since, all the variables have positive correlation, except NSE AGE which has negative correlation. The subsequent subsection of the research presents the multiple regression results.

Table 4. GMM regression result

\begin{tabular}{|l|c|c|c|c|}
\hline \multicolumn{1}{|c|}{ Variable } & Coefficient & Z-statistic & Probability & VIF \\
\hline PE & 0.0865 & $5.06^{\star \star \star}$ & 0.000 & \\
\hline FEMALE & 1.4014 & $2.46^{\star \star}$ & 0.014 & 1.30 \\
\hline DIRCOM & 3.4249 & $3.63^{\star \star \star}$ & 0.000 & 1.14 \\
\hline
\end{tabular}


Table 4 (cont.). GMM regression results

\begin{tabular}{|l|c|c|c|c|}
\hline \multicolumn{1}{|c|}{ Variable } & Coefficient & Z-statistic & Probability & VIF \\
\hline MSH & 4.1200 & $2.37^{* \star}$ & 0.018 & 1.24 \\
\hline RISK & 0.9862 & 1.40 & 1.162 & 1.29 \\
\hline NSE AGE & 0.2266 & $3.47^{* \star *}$ & 0.001 & 1.23 \\
\hline SIZE & 2.0917 & $2.30^{* \star}$ & 0.021 & 1.71 \\
\hline INTERCEPT & -11.7358 & -1.40 & 0.159 & \\
\hline INDUSTRY \& YEAR EFFECT & Yes & Yes & & 1.30 \\
\hline MEAN VIF & & & & \\
\hline AR1 & 0.014 & & & \\
AR2 & 0.201 & & & \\
\hline HANSEN J & 0.193 & & & \\
\hline SARGAN TEST & 0.984 & & & \\
\hline NO. OF OBSERVATIONS & 500 & & & \\
\hline
\end{tabular}

Note: GMM regression is significant at $* * * 1 \%, * * 5 \%$ and $* 10 \%$, respectively.

3.1. Discussions of regression results. The coefficient for female directorship is 1.4014 to price-earnings multiple indicating that for every increase in female directorship PE multiple will have a corresponding increase of 1.4014 Nigerian Naira (NGN). The probability of the explanatory variable (female directorship) is positive and significant at (0.014) 5\% level. This means that positive reasonable relationship exists between board gender diversity measured my presence of females on board and PE multiple of Nigerian listed firms. This result has yielded good response from regulatory authorities' recommendations to companies to constitute their boards in consideration of gender diversity for increased monitoring. Evidence from the results provides a convincing justification for accepting the study hypothesis that female representation on the firm board increases the value of shareholders. The findings supported the agency theory prediction that diverse board provides additional monitoring mechanism that controls agency problem, thereby increasing the value of the firm. These results conform with the study of Campbell and Minguez (2010). Female board appointments on company board are positively related to company value among the European companies over a continuous period. Similarly, Gul, Srinidhi and $\mathrm{Ng}$ (2011) document that gender diversity of board members increases stock price through the device of public information disclosure in larger firms and by boosting confidential evidence gathering in smaller firms. However, the results contradict the findings of Chapple and Humphrey (2013) which report a negative association of having multiple females on the board and the subsequent company performance. Also, Adams (2015) reported negative effect of female on board small firms performance.

The coefficient for director compensation on priceearnings multiple is 3.4249 indicating that for every one Naira increase in the compensation for directors, PE multiple of Nigerian firms will increase by 3.4249
Nigerian Naira (NGN). The probability of director compensation is 0.00 positive suggesting a significant positive relationship between directors compensation and PE multiple of Nigerian listed firms. Thus, an increase in the incentive of directors encourages them to exercise monitoring functions to management for better performance and value of the owners. This result provided an insight on the relationship between compensation for directors and equity value of the shareholders in emerging market in Nigeria, for example. Our results supported the agency theory assumption that appropriate compensation for directors could prevent them from engaging in an act that may affect the performance of the company. As such, the value of the shareholders will increase. The results also provide evidence for accepting our hypothesis that predicts the significant positive relationship between director compensation and PE multiple of Nigerian listed firms. The study conforms with the findings of Perry and Zenner (2001) who conducted research on pay and performance relationship and found that incentive based compensation for company directors influences the degree of monitoring, and companies can align directors and shareholders interest. Similarly, Minnick, Unal and Yang (2009) established that banks whose chief executive officers have higher pay for performance have significant better abnormal share returns. Also, Cheng et al. (2015) reported that pay to directors is tied to long company performance. However, the results contradict the findings of Jensen and Murphy (1990) which established a weak relationship between compensation for directors and subsequent company performance. Equally, the report falls in both levels of chief executive officer pay per year and the pay to performance relationship. Also, Campbell and Wasley (1999) found that executives can occasionally structure compensation policies at the detriment of shareholders. To conclude, $\mathrm{Li}$ et al. (2008) established that stock options for directors exposed company to risk taking. 
The coefficient for managerial shareholding is 4.1200 to PE multiple indicating that for every increase in managerial share ownership PE multiple will have a corresponding increase of 4.1200 Nigerian Naira (NGN). The probability of managerial shareholding is 0.018 positive suggesting a significant relationship between the explanatory variable (managerial shareholding) and explained variable PE multiple. The relationship is positive and significant at 5\% significant level. Furthermore, evidence from the results justifies the acceptance of our hypothesis that predicts the significant positive relationship between managerial share ownership and PE multiple of Nigerian firms. The GMM results reaffirmed the agency theory prediction that management share ownership minimizes agency problem. Where managers have shareholding in the company, their management function creates more value to the company. This is because any adverse action taken by management on behalf of the company could also affect managers share stake. These results provided additional support for the management share ownership as means of reducing agency problem. The results conform with the findings of Lemmon and Lins (2003) that managerial share ownership has significant positive impact on the stock return of selected companies of East Asian countries during the East Asian financial crisis period. Similarly, according to Masulis and Mobbs (2011), firms with insider shareholding have better operating performance and book ratio. These firms make better purchase decisions, have healthier cash holdings, and less overstatement of firm earnings. However, their study opposes the findings of Sanda et al. (2005) who report no significant relationship between ownership of directors and price-earnings ratio of the selected firms. Similarly, Dadidson (2002) reported a negative association between stock held by inside directors and abnormal stock returns of selected firms in the US.

On the one hand, the two control variables (size and the company year of listing) are statistically significant at $1 \%$ level of significance with price-earnings multiple of Nigerian firms. The relationship between risk and price-earnings multiple, on the other hand, is positive, however, not statistically significant. In addition to the risk, NSE age and size, the control for the industry specific factor and year effect has boosted the GMM regression results.

3.2. Post estimation test. The Arellano-Bond test indicates the non-existence of autocorrelation for the GMM regression results. According to the ArellanoBond, in the first instance, it is 0.090, but rectified, in the second instance, with 0.98 values. The test for Arellano-Bond is normally conducted on the error term differences, hence, autocorrelation of the error terms is expected in the first period, because they are mathematically correlated. The Hansen $\mathrm{J}$ result of 0.36 shows that the rules of GMM are not methodically violated signifying that the moment conditions are well-specified for the system GMM conditions. The variance inflation factor (VIF) is always expected to be lower than 10 (Vafeas \& Theodorou, 1998). In this model, all the VIF for all the explanatory variables and control variables are less than 2 suggesting the absence of multicollinearity in the model.

\section{Concluding remark}

This study empirically examined the effects of three corporate governance variables, namely, female directorship, director compensation, and managerial shareholding, and the price-earnings multiple of Nigerian firms. The study used dynamic panel regression model (GMM) to take care of the endogeneity problem established in the literature between the explained and the explanatory variables. It found that relationship exists between the three explanatory variables and PE multiple of listed firms in Nigeria. Based on the findings from the GMM regression results, the study concludes that female directorship, director compensation and managerial shareholding serve as predicting factors to price-earnings multiple of Nigerian firms. The study serves as a remedy to most of the previous findings that estimate static panel regression model which does not solve the endogeneity problem. It, therefore, recommends an increase in the number of females in the Nigerian corporate board's additional incentive for directors to serve as motivation for them to give their utmost best to the company. Lastly, the study recommends additional stake of directors in the company shares to give further support for the reduction of the agency problem.

\section{Implication of the study}

This study empirically investigated the three corporate governance variables in relation to priceearnings multiple of Nigerian listed firms. The implication of this finding suggests that regulatory provisions in the issued governance code provide evidence that those codes have corresponding value to shareholders. This, therefore, suggests that firms in Nigeria should continue to be gender sensitive in the compositions of corporate boards. In addition to female representation, compensation for directors also played an important role to the value of owners. The evidence obtained from the study lends support to other studies conducted in different environments, which suggest ownership of management as a way of reducing agency problem, thereby increasing the value of owners. 


\section{Limitations and suggestions for further research}

Although, this study used the dynamic regression (GMM) as a remedy to most of the previous studies that used static panel (pool OLS, fixed and random effects) model. However, it could make a generalization on the other corporate governance variables. This study, therefore, recommends the investigation of other corporate governance variables using a similar methodology to ascertain whether they could also predict price-earnings multiple. The study also recommends a research on individual corporate governance variables on sector bases to validate this finding. Lastly, it recommends similar research in a different environment using, possibly, the same methodology.

\section{References}

1. Abdullah, S.N., Ismail, K.N.I.K. \& Nachum, L. (2016). Does having women on boards create value? The impact of societal perceptions and corporate governance in emerging markets, Strategic Management Journal, 37 (3), pp. $466-476$.

2. Adams, R.B. (2015). Women on boards: The superheroes of tomorrow? Working Paper, University of New South Wales, November, 2, pp. 1-54.

3. Adams, R.B. \& Ferreira, D. (2009). Women in the boardroom and their impact on governance and performance, Journal of Financial Economics, 94, pp. 291-309.

4. Alford, A. (1992). The effect of the set of comparable firms on the accuracy of the price-earnings valuation method, Journal of Accounting Research, 30 (1), pp. 94-108.

5. Antonios, S., Ioannis, S. \& Panagiotis, A. (2012). Equity valuation with the use of multiples, American Journal of Applied Sciences, 9, pp. 60-65.

6. Arellano, M. \& Bond, S. (1998). Dynamic panel data estimation using DPD98: A guide for users, Manuscript, Oxford University, (December), pp. 1-27.

7. Arun, T.G., Almahrog, Y.E. \& Ali Aribi, Z. (2015). Female directors and earnings management: Evidence from UK companies, International Review of Financial Analysis, 39, pp. 137-146.

8. Baker, G.P. (1988). Discussion of an analysis of the use of accounting and market measures of performance in executive compensation contracts, Journal of Accounting Research, 25, pp. 126-130.

9. Baltagi, B.H. (2005). Econometric Analysis of Panel Data. John Wiley \& Sons Ltd, The Atrium, Southern Gate, Chichester, West Sussex PO19 8SQ, England.

10. Becker, T.E. (2005). Potential problems in the statistical control of variables in organizational research: A qualitative analysis with recommendations, Organizational Research Methods, 8, pp. 274-289.

11. Blundell, R. \& Bond, S. (2000). No Title No Title, Journal of Chemical Information and Modeling, 53 (3), pp. 1689-1699.

12. Brick, I.E., Palmon, O. \& Wald, J.K. (2006). CEO compensation, director compensation, and firm performance: Evidence of cronyism? Journal of Corporate Finance, 12, pp. 403-423.

13. Campbell, J.C. \& Wasley, E.C. (1999). Stock-based incentive contracts and managerial performance: The case of Ralston Purina Company, Journal of Financial Economics, 51, pp. 195-217.

14. Campbell, K. \& Minguez Vera, A. (2010). Female board appointments and firm valuation: short and long-term effects, Journal of Management \& Governance, 14, pp. 37-59.

15. Carter, D.A., Simkins, B.J. \& Simpson, W.G. (2003). Corporate governance, board diversity, and firm value, The Financial Review, 38, pp. 33-54.

16. Chapple, L. \& Humphrey, J.E. (2013). Does board gender diversity have a financial impact? Evidence using stock portfolio performance, Journal of Business Ethics, 23, pp. 1-46.

17. Cheng, I.H., Hong, H. \& Scheinkman, J.A. (2015). Yesterday's Heroes: Compensation and Risk at Financial Firms, Journal of Finance, 70 (2), pp. 839-879.

18. Core, J.E., Holthausen, R.W. \& Larcker, D.F. (1999). Corporate governance, chief executive officer compensation, and firm performance, Journal of Financial Economics, 51, pp. 371-406.

19. Dadidson, W.N., Rosenstein, S. \& Sundaram, S. (2002). An Empirical analysis of cancelled mergers, board composition and ownership structure, Applied Financial Economics, 12, pp. 485-491.

20. Damodaran, A. (2006). Valuation approaches and metrics: A survey of the theory and evidence. Working Paper Series, Stern School of Business. New York City's Greenwich Village.

21. Delgado-García, J.B., Quevedo-Puente, E. De \& Fuente-Sabaté, J.M. De. (2010). The impact of ownership structure on corporate reputation: Evidence from Spain, Corporate Governance: An International Review, 18 (6), pp. 540-556.

22. Demsetz, H. \& Lehn, K. (1985). The structure of corporate ownership: causes and consequences, Journal of Political Economy, 93, pp. 1155-1177.

23. Denis, D.J., Denis, D.K. \& Sarin, A. (1997). Ownership structure and top executive turnover, Journal of Financial Economics, 45, pp. 1-29.

24. Dezso, C.L. \& Ross, D.G. (2012). Does female representation in top management improve firm performance? A panel data investigation, Strategic Management Journal, 33, pp. 1072-1089.

25. Ellwood, S. \& Garcia-Lacalle, J. (2015). The influence of presence and position of women on the boards of directors, Journal of Business Ethics, 30, pp. 1-50.

26. Farrell, K.A. \& Hersch, P.L. (2005). Additions to corporate boards: the effect of gender, Journal of Corporate Finance, 11, pp. 85-106. 
27. Fenwick, G.D. \& Neal, D.J. (2001). Effect of gender composition on group performance, Gender, Work and Organization, 8, pp. 1-21.

28. Fidrmuc, J.P., Goergen, M. \& Renneboog, L.U.C. (2006). Insider trading, news releases, and ownership concentration, Journal of Finance, 61, pp. 2931-2973.

29. Gul, F.A., Srinidhi, B. \& Ng, A.C. (2011). Does board gender diversity improve the informativeness of stock prices? Journal of Accounting and Economics, 51, pp. 314-338.

30. Healy, P.M. (1985). The effect of bonus schemes on accounting decisions, Journal of Accounting and Economics, 7, pp. 85-107.

31. Hermalin, B.B.E. \& Weisbach, M.S. (1998). Endogenously chosen boards of directors and their monitoring of the CEO, The American Economic Review, 88, pp. 96-118.

32. Higgs report. (2003). The higgs working group for the workshop: Summary report. TeV Colliders", Les Houches, France.

33. Hjelmstad, M., Marshall, A. \& Walmsley, T. (2006). Open market share repurchases Open market share purchases in the UK: evidence on the agency theory of free cash flow, Applied Financial Economics Letters, 2, pp. 383-387.

34. Jensen, M.C. \& Murphy, K.J. (1990). Performance pay and top-management incentives, Journal of Political Economy, 98, pp. 225-266.

35. Kang, E. \& Ding, D.K. (2009). Investor Reaction to Women Directors, Journal of Business Research, 63 (30), pp. 1-14.

36. Keloharju, M. \& Kulp, K. (1996). Market-to-book ratios, equity retention, and management ownership in Finnish initial public offerings, Journal of Banking \& Finance, 20, pp. 1583-1599.

37. Lemmon, M.L. \& Lins, K.V. (2003). Ownership structure, corporate governance, and firm value: Evidence from the East Asian financial crisis, The Journal of Finance, 58, pp. 1445-1468.

38. Li, D., Eden, L., Hitt, M.A. \& Ireland, R.D. (2008). Friends, acquaintances, or strangers? Partner selection in R\&D alliances, Academy of Management Journal, 51 (2), pp. 315-334.

39. Li, F. \& Subrahmanyam, A. (2009). Executive Compensation and Investor Clientele, Coporate Ownership and Control, 6 (4), pp. 249-332.

40. Loderer, C. \& Waelchli, U. (2009). Firm age and performance. In Finance Association Meetings in and SGF Conference proceedings (pp. 1-44). Chicago, US.

41. Masulis, R.W. \& Mobbs, S. (2011). Are All Inside Directors the Same? Evidence from the External Directorship Market, The Journal of Finance, 66 (3), pp. 823-872.

42. Masulis, R.W., Wang, C. \& Xie, F. (2014). Corporate Governance and Acquirer Returns, The Journal of Finance, 62 (4), pp. 1851-1889.

43. Meek, G.K., Roberts, C.B. \& Gray, S.J. (1995). Factors influencing voluntary annual report disclosures by U.S., U.K. and continental European multinational corporations, Journal of International Business Studies, 26, pp. 555-572.

44. Mehran, H. (1995). Executive compensation structure, ownership, and firm performance Wallace, Journal of Financial Economics, 38, pp. 163-184.

45. Miller, T. \& Triana, M. del C. (2009). Demographic diversity in the boardroom: Mediators of the board diversity firm performance relationship, Journal of Management Studies, 45, pp. 755-788.

46. Minnick, K., Unal, H. \& Yang, L. (2009). Pay for performance? CEO compensation and acquirer returns in BHCs CEO compensation and acquirer returns in BHCs. In 2009 China International Finance Conference, pp. 1-42.

47. Morey, M., Gottesman, A., Baker, E. \& Godridge, B. (2009). Does better corporate governance result in higher valuations in emerging markets? Another examination using a new data set, Journal of Banking \& Finance, 33, pp. 254-262.

48. Mosley, L. \& Singer, D.A. (2008). Taking stock seriously: Equity-market government financial policy, and financial globalization, International Studies Quarterly, 52, pp. 405-425.

49. Mustapha, M. \& Che Ahmad, A. (2011). Agency theory and managerial ownership: evidence from Malaysia, Managerial Auditing Journal, 26 (5), pp. 419-436.

50. Muttakin, M.B., Khan, A. \& Subramaniam, N. (2015). Firm characteristics, board diversity and corporate social responsibility. Evidence from Bangladesh, Pacific Accounting Review, 27 (3), pp. 353-372.

51. Pagano, P. \& Schivardi, F. (2003). Firm size distribution and growth, Scandinavian Journal of Economics, 105, pp. 255-274.

52. Penman, S.H. (2006). Valuation, capital budgeting, and value-based management, Journal of Applied Corporate Finance, 18, pp. 1-10.

53. Perry, T. \& Zenner, M. (2001). Pay for performance? Government regulation and the structure of compensation contracts, Journal of Financial Economics, 62, pp. 453-488.

54. Phan, P.H. (2001). Corporate governance in the newly emerging economies, Asia Pacific Journal of Management, 18, pp. 131-136.

55. Rose, C. (2007). Does female board representation influence firm performance? The Danish evidence, Corporate Governance, 15, pp. 404-413.

56. Sanda, A., Mikailu, S.A. \& Garba, T. (2005). Corporate governance mechanisms and firm financial performance in Nigeria. In The African Economic Research Consortium Nairobi, Kenya, pp. 1-47.

57. Schreiner, A. (2007). Equity valuation using multiples: An empirical investigation. University of St. Gallen Graduate-Austria. 
58. Sehgal, S. \& Pandey, A. (2010). Equity valuation using price multiples: evidence from India, Asian Academy of Management Journal of Accounting and Finance, 6, pp. 89-108.

59. Shleifer, A. \& Vishny, R.W. (1997). A survey of corporate governance, Journal of Finance, 52, pp. 737-783.

60. Short, H. \& Keasey, K. (1999). Managerial ownership and the performance of firms: Evidence from the UK, Journal of Corporate Finance, 5, pp. 70-101.

61. Stulz, R. (1988). Managerial control of voting rights, Journal of Financial Economics, 20, pp. 25-54.

62. Terjesen, S., Couto, E.B. \& Francisco, P.M. (2015). Does the presence of independent and female directors impact firm performance? A multi-country study of board diversity, Journal of Management and Governance, 30, pp. 1-37.

63. Yeo, G.H.H., Chen, S. \& Lee, C. (1999). Effects of executive share option plans on shareholder wealth and firm performance: The Singapore evidence, The Financial Review, 34, pp. 1-20. 